\title{
Professional Sport, Health and Sports Law
}

\author{
Siniša Franjić* \\ Faculty of Medicine, Josip Juraj Strossmayer, University of Osijek, Republic of Croatia, Europe
}

Submission: January 14, 2019; Published: February 22, 2019

*Corresponding author: Sinisa Franjic, Josip Juraj Strossmayer, University of Osijek, Republic of Croatia, Europe

\begin{abstract}
Sport is not only healthy but has both legal and economic aspects. News from the world of professional sports almost always have a legal background, and even mass sports, sports within sports clubs and sports in schools are increasingly confronted with legal issues. Sport and legal regulation are reflected in the deep linkage, as the most important and essential element of sport is its legal regulation. This applies in particular to the competition rules as well as to other supporting elements of the sport organization. In addition, sports activities often take place outside state borders, whereby their international dimension is expressed.
\end{abstract}

Keywords: Sport; Law; Health; Athlete

\section{Introduction}

For the majority of the population, sport is a past time that is played as a non-vocational leisure activity or watched on television or other media platforms as part of a healthy, balanced lifestyle [1]. For a few talented individuals, it is a way of earning a living. Sport as a professional occupation requires physical skill, mental focus and dedication to a disciplined way of living that includes eating well, training and sleeping. It is also a career of short duration for most athletes. A football player, tennis player, $100 \mathrm{~m}$ sprinter, rugby player, Formula 1 driver, netball player, hockey player, speed skater, cricketer or basketball player, must maximize their career earning potential over a short period of time by providing athletic services to a club, team or federation, or through selling their image for product endorsement. The amount of money or benefits received for services and the working conditions in which those services are provided are important to a professional athlete, but those concerns are not unique to professional athletes. A worker, employee or independent contractor in any industry considers the amount of money and benefits he or she receives and health and safety in the work environment to be important. An employee desires fair working conditions in return for the services provided. Owing to the scarcity of talented athletes, the short duration of a professional career and competition for a player's services, the remuneration or market value of a professional athlete's services can be quite high for some athletes, though not for all. Some players in certain sports have to supplement their sports related earnings with other jobs or forgo sport as an occupation altogether. The disputed employment conditions in professional sport are many and varied but the employment terms in each sport will discuss relate to wages, contract termination and access to employment or eligibility. Overly restrictive working conditions that limit wages, restrict movement between employers and a player's opportunity to take up employment in a competition were initially introduced unilaterally in most professional sports at a time when employment and labour laws were not as robust as contemporary laws. The conditions were generally implemented to serve the economic interests of the clubs, teams, league or federation. Over time professional athletes in some sports at a national level have organized collectively and with the support of national labour relations law have collectively negotiated employment terms. Collective bargaining has enabled athletes in some competitions to become involved in the determination of working conditions.

\section{Discussion}

\section{Legal Regulation}

The regulation of sport has developed according to the history of each country; there is greater government intervention in some countries than in others [1]. Most sports in the European Union are organized within a regulatory structure that extends internationally and assumes the form of a pyramid. At the apex of the pyramid is an international federation, a private association of national federations for the sport. Its authority to regulate the sport and organize competitions between national teams will usually derive from a private contract between members. A national federation, in turn, will be an association of clubs or associations that govern the sport at a national level. A national federation is responsible for organizing, promoting and governing all aspects of the sport in its jurisdiction. Through membership to the international federation, the national federation will be 
contractually obliged to adhere and enforce an international federation's rules but only to the extent permitted by national law. Insofar as there is a conflict between an international federation rule and national law, the latter will usually prevail.

An international and national federation will require revenue to pay administration costs and develop a sport internationally or nationally. Revenue earned in a competition between national teams will be used to pay the international federation's administration costs and distributed to national federations to support the development of the sport globally. At a national level the commercial success of a professional league supports the development of the sport at grassroots level through payments made by the league to semi-professional and amateur clubs. A successful youth development policy and talent identification program at grassroots-level can assist with the flow of talented players into a professional league and also the success potential of a national team. A federation or league is usually the ultimate disciplinary authority for conduct that arises during a match. It may also adopt regulatory rules on a wide range of matters through decision-making processes outlined in its constitution. The legal status of the federation as a public or private entity may determine the extent to which it is legally obliged to consider other affected interests in its regulatory decision-making processes.

\section{Employment}

The basis for an employment relationship is an employment contract [1]. The tests for establishing whether an employment contract (or a contract of service as it is frequently termed) exists are prescribed in common law. If an employment contract does not exist, a party may be considered in law as a worker or selfemployed. The advantage of employee status is that it entitles a person to minimum statutory employment rights for which an independent contractor or a worker may not be eligible. Employee status is also relevant for issues of vicarious liability under tort law, the application of trade union law, health and safety legislation and tax law. In the context of modern contractual relationships and working arrangements, determining whether a contract of service exists can be difficult. The tests that the courts have devised relate to the degree of control that one party exerts over the other, the presence or absence of a mutual obligation, the integration of one party into the other party's enterprise, and the economic reality of the situation in which the contract exists. No single test is determinative of employee status and the weight ascribed to each feature of the relationship differs between cases. The label that the parties place on the relationship is also not determinative of the status of a particular working arrangement. Historically, control was the determining factor. If a person was "subject to the command of his master as to the manner in which he shall do his work", then that person was employed.

\section{Athletes}

Sport is a global phenomenon that performs many important functions in contemporary society [2]. It is most often mentioned in its positive role as a tool contributing towards education of children and young adults, a means of social integration and overcoming cultural differences, a major source of employment in modern society, and a vehicle towards better mental and physical health. In addition, in its socio-cultural dimension, sport is a part of the popular culture that entertains billions of people worldwide. Many people identify with their local or national team, follow their games 'religiously' and derive a sense of pride if their team wins. This effect that sport has on masses and its immense cultural importance has made it a most valuable content for broadcasters, as well as a target for political propaganda. Sporting activity crosses a wide range of legal subjects such as contract law, tort law, intellectual property law, competition law, constitutional law, labor law, internal market law and fundamental rights. It involves everyone (people of all ages, genders, races, etc.) at all levels (beginners, recreationists, amateurs, semiprofessionals and professionals) and in all capacities (spectators and television viewers, players, coaches, medical doctors, psychologists, agents, etc.).

During the recent decades the number of children and youth involved in organized, competitive sports has increased. As a consequence, youth sports in general, and more specifically, elite sports for teenage youth are presently a public phenomenon [3]. Changes in expectations of performance at top levels, together with the extreme training demands and the controlling of young athletes by their coaches, parents, and the peer environment, has resulted in public and medical concerns. The prerequisites of athletic success in many sports rely to a great extent upon physical characteristics, including anthropometric dimensions, somatotype, and body composition. The relevance of morphology is especially evident in 'artistic' sports, such as ballet, gymnastics, figure skating, and diving, wherein the body is a primary element in obtaining high performance scores, and scoring may be influenced by the perceptions of the judges.

The importance of a well-suited 'gymnastic specific' body build for reaching the highest level in artistic gymnastics is well documented. On average, compared to reference peers of the same chronological age, top-level female gymnasts are characterized by a short stature, light body mass, narrow hips with relatively broad shoulders, an ectomesomorphic somatotype, a low percentage of body fat with a high fat-free mass, and later maturation. Gymnastic training commences at a very young age for example, in are presentative sample of world-ranking female gymnasts starting age was about 7.5 years. In many teenage girls there is a latent pressure to obtain the 'ideal' gymnastic-specific body build, especially to keep their weight, and more specifically their percentage of body fat, as low as possible. This can lead to substantive physical and psychological problems. From a medical, health, and gymnastic-technical perspective, it is important to estimate body composition characteristics in these young athletes as accurately as possible. 
One of the most important facts for every athlete is their nutritional needs. The relationship between nutrition and sports performance has become increasingly important due to the rise in the number of athletes and active people that need qualified professionals to optimize their food choices, thus supporting exercise performance and health status [4]. Based on the previous assumption, the role of the nutritionist in sports such as handball will require knowledge of the sport-specific physiological demands of training and competition to be able to implement dietary recommendations and strategies within the framework of a multi-professional sports team. An individual approach is needed to meet each athlete's nutritional and hydration needs, assessing nutritional status and guiding and advising based on the evidence for health and exercise performance in athletes, sports organizations, and physically active people.

In order to stay healthy and avoid infectious diseases, athletes need an optimally working immune system which can handle viruses, bacteria and other microbes encountered every day [5]. The immune system with its many cellular and soluble componentsais dispersed throughout most of the body with connecting blood and lymph vessels as a communication web between the different immuno-active tissues. There are no 'headquarters' in the immune system, in the way that the brain governs most of the nervous system. Nevertheless, certain immune cells and signal molecules circulating between the various organs and tissues have a paramount role in coordinating both local and systemic responses when the immune system is activated.

With regard to its strategic operations, the immune system resembles a military defence system with surveillance, resistance and attacking functions. These operations are closely integrated and essential for a well-functioning immune system, as intelligence service, air-raid shelters and missiles are important parts of a national defence system. However, the various immune cells and soluble components come into play in a different way, depending on whether the body is at rest (state of peace), or is being challenged (state of stress) or invaded by microorganisms (state of war). Additionally, the immune response depends on what type of stimuli activates the immune system. Physical activity and, in particular, strenuous exercise such as cross country skiing is a potent stimulus for the immune system, which may result in both activation and depression of several immune functions.

\section{Medical Tests}

Physicians acquire information in many ways [6]. They ask questions. They perform physical examinations. They use their senses of touch and smell. And, increasingly, they prescribe various tests. Tests to measure the concentration of constituents of blood, urine, sputum, and other body components have long been available. Newer tests identify genetic markers associated with the advent of various diseases. Simple x-ray examinations, once the only noninvasive way to look inside the human body, and exploratory surgery have been supplemented or replaced by ultrasound, radioisotopes, magnetic resonance imaging, fiber optics, and computed tomography-technologies that often supply more and better information than common x-rays. But such information is costly and does not always translate into better treatment or improved patient outcomes.

An ideal test is cheap, produces no side effects, and is always right in two senses: it correctly identifies a pathology whenever it is present, and it correctly indicates its absence whenever it is not present. Inaccuracy in either sense is clearly costly when a beneficial treatment is available. But signaling an abnormal condition when none is present is also damaging because it may expose healthy patients to needless worry, costly treatments, and perhaps to harmful side effects.

A new test may reduce one but not both of these errors. In such cases, great care must be exercised in selecting patients on whom the test will be used, particularly when the new test is more costly or risky than the old. But even accurate tests can be worthlessor worse-when, for instance, effective treatments are unavailable for the condition. For example, while a test exists to identify the gene that results in amyotrophic lateral sclerosis (Lou Gehrig's disease), possible carriers of the gene sometimes elect not to have the test as no effective treatment for the condition exists. What would be the impact of resource limits on investments in improved diagnostic technology? Decisionmakers subject to resource limits are likely to be particularly cautious and skeptical before investing in allegedly superior diagnostic procedures, because even tests with greater accuracy may not improve diagnoses, treatments, or outcomes. Health care decisionmakers who are subject to budget limits would seek evidence that the new information justifies added costs and risks to patients from side effects.

\section{Doping}

Just imagine for a moment a sports law attorney sitting with his or her athlete-client, the client swearing that he has no clue how that substance with the unpronounceable name ended up in his urine and claiming that his innocence must be recognized [7]. Counsel then faces the delicate task of explaining to the athlete that the rules do provide for the elimination of all sanctions in the absence of fault, but that, unfortunately, he has the burden of proving such absence of fault and he will not be permitted to do so unless he is able to establish the origin of the substance. Alternatively, imagine same counsel having to tell another athleteclient that a low concentration of the substance in the sample might well have assisted in demonstrating that she had no intent to enhance her performance. Unfortunately, however, this data is not available since the laboratory did not measure the concentration. This was because a quantitative analysis was not required under applicable rules.

Conversely, when assisting a sports federation, counsel may find it much harder to obtain a heavy sanction against an "accomplished" doping cheat appearing with the right armada of experts, than against an "incompetent" (and usually penniless) 
scatterbrain, even if his mother appears to testify to what an honest guy he has always been. In the years that followed, antidoping measures expanded in response to the emergence of new forms of doping and a growing interest in and understanding of the nature of the problem [8]. Some key features of this expansion included growth in the number of sports and events subject to doping controls, the development of reliable scientific techniques for the detection of prohibited substances and methods, the accreditation of testing laboratories by the IOC, the introduction of out-ofcompetition testing and increased reporting (often in sensational terms) in the news media of incidents of doping. The importance and increasing complexity of antidoping rules attracted the attention of national governments. In turn, this led to judicial and parliamentary inquiries, domestic legislation prohibiting doping, dedicated antidoping agencies, and international treaties and arrangements.

Despite this activity, antidoping efforts were seriously balkanized, possibly compromised, and faced major shortcomings by the mid to late 1990s. This was largely because of differences in approach among sports and across national legal systems as well as the circumstance that not all sports and competitions were affiliated with the Olympic Movement. Although the IOC had provided significant leadership, there was no uniform list of prohibited substances and methods worldwide. Some sports had no antidoping rules whatsoever. Furthermore, concerns were wide spread that some states and sports paid lip service to the antidoping cause while systematically pursuing doping practices or shielding transgressing athletes from the full weight of disciplinary processes by displaying "hometown" favoritism.

\section{Conclusion}

Sport is a multi-dimensional and complex phenomenon. In addition to competitions, the field of sport encompasses social, psychological, economic, political, pedagogical, scientific, medical, philosophical, religious, cultural, legal and other values. Sport is a social phenomenon with specific social functions and is an expression of certain social phenomena. Sporting or any other form of physical activity is useful and desirable, both for adults and children. Sporting is the main factor for successful psycho-physical growth in the life of a young person. Exercise keeps and improves health, affects physical development and the development of traits and skills. Sport also influences the development of personality, the strengthening of the will, the emotional maturation, because in the competitive sport the athlete passes for a short time through different emotional states. The development of sports and the ever increasing political and economic role of sport within society has meant the immediate development and expansion of Sport law. Sport law as an independent branch of law has recently become more and more active and it is inseparable linked to the so-called. traditional legal fields, such as, for example, Contract law, Tax law and Labor law. A great influence on the development of a special legal field is the fact that sport has a specific position in the society which is primarily result to the autonomous position of certain sports organizations which they have autonomous rules.

\section{References}

1. O'Leary L (2017) Employment and Labour Relations Law in the Premier League, NBA and International Rugby Union, TMC Asser Press, Springer Science + Business Media BV, The Hague, Dordrecht, The Netherlands p. 13-89.

2. Pijetlovic K (2015) EU Sports Law and Breakaway Leagues in Football TMC Asser Press, Springer Science + Business Media BV, The Hague, Dordrecht, The Netherlands p. 2.

3. Claessens AL Delbroek W, Lefevre J (2001) The Use of Different Prediction Equations for the Assessment of Body Composition in Young Female Gymnasts - Is There a Best Equation? in Jürimaäe T, Hills AP (eds) Body Composition Assessment in Children and Adolescents, Karger, Basel, Switzerland pp. 138-139.

4. Molina-López J, Planells E (2018) Nutrition and Hydration for Handball in Laver L, Landreau PH, Seil R, Popovic N (eds) Handball Sports Medicine - Basic Science, Injury Management and Return to Sport, ESSKA, Springer-Verlag GmbH, Berlin, Germany p. 81-82.

5. Ronsen $O$ (2003) Medical aspects of cross country skiing in Rusko H (eds) Handbook of Sports Medicine and Science - Cross Country Skiing, Blackwell Science Ltd, Malden, USA pp. 101-102.

6. Aaron HJ, Schwartz WB, Cox M (2005) Can We Say No - The Challenge of Rationing Health Care, The Brookings Institution, Washington, USA p. 77-78.

7. Viret M (2016) Evidence in Anti-Doping at the Intersection of Science and Law, TMC Asser Press, Springer Science + Business Media BV, The Hague, Dordrecht, The Netherlands p. 2.

8. Mitten MJ, Opie H (2012) Sports Law: Implications for the Development of International, Comparative, and National Law and Global Dispute Resolution in Siekmann RCR, Soek J (eds) Lex Sportiva - What is Sports Law, TMC Asser Press, Springer Science + Business Media BV, The Hague, Dordrecht, The Netherlands p. 180-181. 

(C) Commons Attribution 4.0 License

DOI: 10.19080/JPFMTS.2019.06.555678
Your next submission with Juniper Publishers will reach you the below assets

- Quality Editorial service

- Swift Peer Review

- Reprints availability

- E-prints Service

- Manuscript Podcast for convenient understanding

- Global attainment for your research

- Manuscript accessibility in different formats

( Pdf, E-pub, Full Text, Audio)

- Unceasing customer service

Track the below URL for one-step submission https://juniperpublishers.com/online-submission.php 